\title{
СТАТЬИ
}

UDC 340.147

\section{Heritage: How to remain relevant following the virus crisis?}

\section{Saša Srećković}

For citation: Srećković, Saša. 2020. Heritage: How to remain relevant following the virus crisis? Pravovedenie 64 (1): 15-22. https://doi.org/10.21638/spbu25.2020.101

\begin{abstract}
The article states that despite the creation of the UNESCO fund aimed at International assistance by means of which State parties to the Convention for Safeguarding of Intangible Cultural Heritage, inter alia, can address problems arising from catastrophes and emergencies. However, the devastating effects of the pandemic on heritage are yet to be expected. Due to the known recent circumstances, without mobility of people and their mutual contacts, and without physical access to the built heritage and museums, there will be no income for local people living in their surroundings. Another problem is related to the intangible expressions of heritage due to inevitable economic turbulences subsequent to the pandemic, and even due to the recent political turmoil caused by various related factors, such as the behavior demonstrated by different governments while facing the crisis and consequent revolts in many communities worldwide. While clear solutions for affected heritage following the crisis are still not on the horizon, we may assume that in the near future there will be an increase of interest in environmental studies. Many will reflect upon the sustainable use of resources and their relevance for heritage (such as agrarian heritage, particularly in regard to food security; traditional medicine or cultural rights and intellectual property in the same context). While there is no doubt that digital tools for reviewing (tangible) heritage will only progress over time, the question is to what extent will living experiences of heritage be affordable to people, at least in the forthcoming period. An adequate response to a global disaster will certainly integrate heritage into policies such as territorial urban/rural planning and various intersectoral activities, and examples already exist in projects funded and supported by the European Union. Despite the weakening of available resources as a result of the pandemic, heritage institutions should also increasingly allow for more democratic inclusion of communities into the issues of inventorying and safeguarding heritage, through mechanisms such as participatory mapping and the like.
\end{abstract}

Keywords: cultural heritage, Intangible Cultural Heritage, emergencies, pandemic, consequences, economic turbulences, response, agrarian heritage, community participation.

\section{Introduction}

In these rather monothematic times any deliberation on outcomes of the actual crisis is often at risk of discovering "hot water" and many reflections around the pandemic of COVID-19 may appear annoying and all but original. However, I took that risk and

Saša Srećković - Ba. Sci. in Ethnology/Anthropology, Museum counselor, Ethnographic Museum in Belgrade, 13, Studentski, Beograd, 11000, Serbia; sasasrec@gmail.com

(c) St. Petersburg State University, 2021 
challenge to say something obvious, and if possible a little bit beyond that while keeping in mind the need to prepare myself for some more bad news, if need be.

Anyway, by introducing this approach to anticipate occurences we could only deal with assumptions about trends that are likely to shape the reality around heritage in the period immediately following the global crisis caused by the corona-virus. Those trends have not demonstrated quite measurable parameters so far in the disciplines such as cultural heritage, but by reading some global and local economic figures that have been already available it is possible to anticipate, at least in rough terms, and draw conclusions based on common sense of how the heritage domain is affected ${ }^{1}$ and how is yet probably going to be affected.

Now, only a few months since its beginning the devastating effects of the actual pandemic on heritage are probably yet to be expected. Logically so, due to the known recent circumstances; without mobility of people and their mutual contacts, and without physical access to built heritage and museums there are neither revenues for professionals in charge of their maintenance and presentation, nor for local people living in their surroundings who so far enjoyed earnings from economical activities within heritage clusters. This is but not some novelty and the already existing adverse effects on economies certainly affect heritage to some degree, such as losses of jobs, global recession, grave losses for travel industry worldwide etc. A number of businesses around heritage sites are certainly not going to be able to start over, at least not that soon. Heritage institutions will not be able to attract masses of visitors, organize events and draw money from programs, probably as long as the vaccine for Covid-19 disease is not in wide public use.

\section{UNESCO and disasters}

And it is important to note that the UNESCO have treated this kind of problems well ahead. Numerous local disasters worldwide (armed conflicts, natural catastrophes) that in turn had affected heritage over many years fed into the pool of experiences that served for drafting various legal documents, publications, plans for response and subsequent actions in the field. As i have been mostly involved with the programs dedicated to intangible cultural heritage I shall recall the most noteworthy recent activities in this field. One of the latest respective events occurred in 2019 as the UNESCO secretariat for intangible cultural heritage launched the expert meeting that concluded in drafting the summary report on principles and operational modalities of dealing with intangible cultural heritage in emergencies ${ }^{2}$. Dual role of intangible cultural heritage is there considered, as heritage possibly affected by emergencies, but also heritage as a tool to help relief of communities during and after emergency situations. In the document there is by no means an exhaustive list of actions, but rather the core principles that can be adapted to local contexts. The term "emergencies" is to be understood to include both conflict situations and disasters caused by natural and human-induced hazards. The report also emphasizes the clear links between tangible and intangible heritage "insomuch as attack on one is often associated with the attack on the other" 3 .

1 We can follow the links indicating some organized efforts internationally to estimate possible damages, such as: https://www.europanostra.org/europa-nostra-launches-wide-consultation-on-the-impact-of-covid-19-on-the-heritage-world, or https://www.canada.ca/en/conservation-institute/services/ conservation-preservation-publications/canadian-conservation-institute-notes/caring-heritage-collections-covid19.html (accessed: 18.12.2020) and https://www.iccrom.org/heritage-crisis-covid-adverseeconomic-impacts (accessed: 18.12.2020).

2 See: https://ich.unesco.org/en/news/what-to-do-for-intangible-cultural-heritage-in-emergencies-13214; https://ich.unesco.org/en/Decisions/14.COM/13 (both accessed: 18.12.2020).

3 Ibid. 
Another UNESCO instrument related to intangible cultural heritage and available for cases of emergencies has been taking effect through the mechanism of International Assistance ${ }^{4}$. The related fund is available to state parties to the Convention for safeguarding of intangible cultural heritage. It can, inter alia, tackle problems arised by various catastrophes and disasters. My strong impression is that this mechanism has been rarely utilized if we take in account possible benefits it can bring to the member countries.

Among the most recent and relevant UNESCO responses to disasters affecting heritage is the web survey among its colleagues that resulted in the web platform on "Living Heritage experiences and the COVID - 19 pandemic": Living heritage as a source of resilience and recovery during crisis ${ }^{5}$. There are cases of online activities and use of digital tools to enhance safeguarding heritage in the period of pandemic in many countries. But there are also interesting experiences from the cases by engaging audiences, such as the fascinating account on living heritage in Flanders, Belgium ${ }^{6}$ and how communities adapt to the situation thereby developing new living heritage forms. And the most recent action UNESCO - COVID 19 Culture response ${ }^{7}$ in four key areas: Sharing culture, Assessing the impact, Support for artists \& cultural professionals and Building capacity.

\section{A shortlist of damages}

The outbreak of pandemic in the first months of 2020 is an unfortunate opportunity to test the guidelines set out in "Intangible cultural heritage in emergencies". The actual global disaster is but a new test for heritage in general. Moreover, it added new elements on a global scale, whereas the former emergencies mostly affected heritage locally. As a result, the total reduction of living human contacts brings along in turn absence of living experiences of heritage, and threatens in turn the livelihood of respective heritage communities. In the meantime many would rely on enjoyment of heritage by means of digital tools and virtual communication. That is surely not enough, since we are aware of the role the heritage play in human lives; these technical tools and appliances are rather suitable to trigger perception and only in part appreciation of heritage.

The particular challenge is facing the heritage institutions. The considerable budget trimmings subsequent to this crisis will affect their operations, in particular in countries where governments do not understand long term effects of investing in the sphere of culture and heritage ${ }^{8}$. Needless to say what kind of consequences we can expect as we recently learned that the Ethnographic Museum in Belgrade, being the focal point for intangible cultural heritage and ethnographic fieldwork in Serbia, would receive exactly zero dinars (0) for the field research in 2020.

And that is not all. Beyond healthcare concerns and immediate economic and social effects the actual crisis unleashed numerous political tensions around the world. I dare say, hand in hand with the virus pandemic the world experiences another pandemic of mistrust in official versions ranging from health care requirements (e. g. vaccination, lockdown) across many other aspects of public service management of the emergency situa-

4 See: https://ich.unesco.org/en/requesting-assistance-00039 (accessed: 18.12.2020).

5 See: https://ich.unesco.org/en/news/unesco-launches-platform-on-living-heritage-and-the-covid-19-pandemic-13263 (accessed: 18.12.2020).

6 See: https://ich.unesco.org/en/living-heritage-experience-and-covid-19-pandemic-01124?id= 00084 (accessed: 18.12.2020).

7 See: https://en.unesco.org/covid19/cultureresponse (accessed: 18.12.2020).

8 The case from Serbia shows that the Ministry of culture was deprived from the previously allocated budget amount due to the outbreak of the pandemic of Covid-19: http://www.seecult.org/vest/o-pomociza-umetnike-u-narednoj-rundi-budzet-za-kulturu-smanjen (accessed: 18.12.2020). 
tion (such as fear of overall surveillance); mistrust of various intensity depending on level of faith the people place in their respective country governments.

What does it have to do with heritage? Perhaps not an immediate reference; however, let us think twice: decisions on (primarily tangible) heritage have been always up to the authorities $^{9}$. How shall various communities of the near future respect heritage interpretations delivered by authorities if they tend to believe lesser and lesser in official interpretations in general? Maybe this is an issue and trouble already brought about with development of civil society. Indeed it appears to be easier with material or tangible heritage in this regard: there are no big disputes over who erected a fortress in some distant past and to whose warrying sides the builders belonged back then: the monument testifies of universal human creation regardless of conflicting parties once upon a time. However, closer to the present time the heritage (and primarily intangible heritage) is subject to different interpretations and estimates of its value. The discipline culture of memory adds nowadays a lot to multiple voices that contribute to interpretations of heritage ${ }^{10}$. Truth for the will, reservations and criticisms caused by different attitudes in this field have been constantly airing long before the pandemic. And now it is taking effect more than ever.

Another issue, the prior unprecedented expansion of digital tools and social media certainly contributed immensely to this polyphony and plurality of (theoretically, possibly equally valued) interpretations. That is undoubtedly going to leave a mark on interpretations of cultural heritage ${ }^{11}$ and respective identities. Authorities do not avail of exclusive access to media any more, though they still control the most influential ones.

And what about virtual pieces of digital culture (messages or posts) that have been overflowing our apps daily - will they be considered elements of intangible cultural heritage soon? As we know the communities in Finland and Germany already initiated Demoscene the art of digital coding to be nominated to the UNESCO international lists lately ${ }^{12}$. Among the outcomes of the current pandemic - albeit not a novelty in form - is a series of postings from various social media and networks, this time with the topic of the pandemic. Some of them distinguish themselves by a comic content, such as funny coronisms ${ }^{13}$, some of them however being quite subversive in nature, thereby reaching beyond the pandemic only and revealing political agendas ${ }^{14}$. Since the latest technology is taking over a great deal of human communication nowadays it is not oddly to expect that digital contents are going to enter the realm of (intangible) heritage at some point - sooner or later.

${ }^{9}$ Blake J. On defining the cultural heritage // The International and Comparative Law Quarterly. 2000. vol. 49, no. 1. P. 68.

10 There are numerous works that endeavor to unravel complex interplay between heritage and memory, such as: Critical perspectives on cultural memory and heritage: construction, transformation and destruction / ed. by V. Apaydin. London: UCL Press, 2020. The following papers, too: Whitehead C., Bozoglu G. Heritage and Memory in Europe: a review of key concepts and frameworks for CoHERE // Critical heritages (Co-HERE). Newcastle University, 2017. P. 2-23; Viejo-Rose D. Cultural heritage and memory: Untangling the ties that bind // Culture \& History Digital Journal. 2015. Vol. 4, no. 2. P. 1-13.

11 The topic is well elaborated in the case studies in the book: Giaccardi E. Heritage and social media: Understanding heritage in a participatory culture. London: Routledge, 2012. See the respective considerations in the chapter dedicated to Social Practice.

12 See: http://demoscene-the-art-of-coding.net (accessed: 18.12.2020).

${ }^{13}$ A colloquial name for such postings as used in Serbia, and probably elswhere, too. The relevant text is published in the Serbian magazine Politika: http://www.politika.rs/sr/clanak/453398/Smeh-podmaskama (accessed: 18.12.2020). Even some museological activities on collecting relevant items related to Corona-visrus are reported to take place. See: https://theconversation.com/us/topics/museums-1517 (accessed: 18.12.2020).

${ }^{14}$ See: https://www.cidob.org/en/publications/publication_series/opinion/seguridad_y_politica_ mundial/coronavirus_infodemics_and_disinformation (accessed: 18.12.2020). 


\section{Other responses}

There are certainly way more questions than answers while facing realities post COVID-19 and its impacts. If we take in consideration these complex realities and circumstances that in various ways concern heritage it is clear that there are (yet) no prescriptions or even guidelines as to how to act for the benefit of heritage following the pandemic. The UNESCO does advocate the significance of this approach, but it is the question of how far it can balance between not only cultural but political agendas of particular countries. While being funded by these state parties, i am afraid one day the UNESCO might end up in the crossfire while pursuing its mission the way the World Health Organization is exposed to now ${ }^{15}$.

We certainly need to follow some global trends that will likely recognize multiple benefits of heritage.

As regards intangible cultural heritage i think there is going to be an increased attention to environmental studies and related heritage expressions. For example, agrarian heritage ${ }^{16}$ may gain on significance, while economies will have to adapt and diversify agricultural production following the global recession caused by the pandemic of COVID-19, but also given the previous devastations caused by some adverse effects of the green revolution and similar trends. The principle of food and nutrition security underlies another actual argument, involving actions aimed at eradication of poverty and hunger, as already envisaged by the 2030 Sustainable Development agenda ${ }^{17}$.

I guess the voices are going to be in turn louder as to the topic of traditional/alternative medicine ${ }^{18}$, too. At the first place we should welcome any inventorying and mapping efforts as regards traditional and indigenous methods. The reason is more than obvious over these days, especially in view of the mentioned global mistrust in institutions. Therefore healthcare institutions are expected to include and allow for multidisciplinary views and more flexible approach beyond interests of particular pharmaceutical companies, just to name one of the globally most neuralgic points ${ }^{19}$.

It is important to emphasize a strong communitarian and social impacts of traditional medicine. One integral apprroach to healthcare includes the issues such as legal protection of rights of patients to choose not only safe and efficient methods, but also culturally acceptable and economically affordable way of self-healing. Though widely practiced (among the poor and rural population, for example) the traditional medicine is rarely integrated in public policies.

Indeed, a strengthened intersectoral cooperation can demonstrate that heritage really matters for economic and social development.

15 See: https://www.who.int/news-room/detail/23-04-2020-who-reports-fivefold-increase-in-cyberattacks-urges-vigilance (accessed: 18.12.2020).

16 See the example of the concept as elaborated by the governmental agencies in Holland: https:// english.cultureelerfgoed.nl/publications/publications/2015/01/01/heritage-as-an-aspect-of-the-common-agricultural-policy (accessed: 18.12.2020). Another contribution within the framework of Sustainable Development is available in the book: Koohafkan P., Altieri M. A. Forgotten Agricultural Heritage: Reconnecting food systems and sustainable development. London: Routledge, 2017. The paramount public document: Howard P., Puri R., Smith L. J., Altierri M. Globally Important Agricultural Heritage Systems: A Scientific Conceptual Framework and Strategic Principles. Available at: http://www.fao.org/3/ap025e/ ap025e.pdf (accessed: 18.12.2020).

17 See: https://sustainabledevelopment.un.org/?menu=1300 (accessed: 18.12.2020).

18 See: Riordan A., Schofield J. Beyond medicine: Traditional medicine as cultural heritage // International Journal of Heritage Studies. 2015. Vol. 21. P. 280-299.

19 Among the numerous case studies see: Russel L. B. Who steals indigenous knowledge? // Proceedings of the Annual Meeting. Cambridge University press (on behalf of American Society of International Law). 2001. Vol.95. P. 153-161. 
In the wake of expected consequences and responses there is probably going to occur some higher degree of democratization of cultural heritage $\mathrm{e}^{20}$ in general. It is because institutions only will not be able to cover all aspects of heritage identification and research, in particular in the immediate period upon the actual pandemic. They will be forced to include communities in their activities more than ever ${ }^{21}$. So among the methods there will be a stronger emphasis on actions such as participatory mapping ${ }^{22}$, inclusion of volunteers etc. The local communitarian interests will be further promoted through social media outreach and digital networks.

The role of legal expertise in all those activities will only rise in time. For one, the many of UNESCO legal documents (treaties, conventions, recommendations etc.) deal exactly with responses to disasters and emergency situations. The same stands for intellectual property issues, the topic that has been otherwise very "hot" all over the world in the recent period. And what i consider we need to integrate more is the issue of cultural rights ${ }^{23}$ and how to give voice to marginal, indigenous communities and various minorities ${ }^{24}$ so as to reduce their pressure on institutions on one hand, but also to mitigate their frustrations of being underrepresented and ignored.

During times of disruptive changes as we are currently experiencing we certainly need increased moral re-considerations and new procedures. Even beyond strictly legal statements we shall desperately need ethical codes of various kinds (regulating behavior betw. experts and communities) where legal expertise is essential or even crucial.

Of course, among the policies that will come to the forefront the investments in education occupy the critical importance. At least we know well in Serbia how it feels like to have a good educational system destroyed, thereby transforming many communities into ready-made consumers of "reality" programs. How to identify and recognize (a socially desirable) heritage is yet going to be our big common concern.

I may also assume that some actual policies of EU will further integrate (intangible) cultural heritage increasingly, such as territorial functional planning ${ }^{25}$ for both urban and rural settlements, creation of smart cities, cultural routes, etc. And, of course the same stands for opportunities enacted by heritage tourism, creative industries etc.

\section{Conclusions}

I addressed some of the most significant short-term outcomes and impacts of the pandemic COVID-19 on heritage, in particular on intangible cultural heritage. The effects may be more or less immediate, some global impacts may not refer to the field of heritage directly, but the various factors together still affect heritage in medium and longer term. As we can see the UNESCO has prepared some adequate responses in its own domain.

20 See for example: The ICOMOS Declaration. Available at: https://whc.unesco.org/en/news/1767 (accessed: 18.12.2020).

21 The statement primarily refers to intangible cultural heritage; among the relevant papers i would recommend: Proschan F. Community involvement in valuing and safeguarding intangible cultural heritage // Reflections on cultural heritage theories and practices / eds K. Van Balen, A. Vandesande. A series by the Raymond Lemaire International Centre for conservation, KU Leuven, 2015. P. 15-21.

${ }^{22}$ La Frenierre J. Mapping heritage: A participatory technique for identifying tangible and intangible cultural heritage // International Journal of the Inclusive Museum. 2008. Vol. 1, no. 1. P. 97-104.

${ }^{23}$ See: https://unesdoc.unesco.org/ark:/48223/pf0000001194 (accessed: 18.12.2020).

24 See: Stamatopoulou E. Cultural rights in international law. Article 27 of the Universal declaration of human rights and beyond. Leiden; Boston: Martinus Nijhoff, 2007. P. 41, 70, 163-170.

25 The subject is well represented within the policies of European Union. See: Bold J., Pickard R. (eds) An Integrated approach to cultural heritage // The Council of Europe's technical co-operation and consultancy program. Strasbourg: Council of Europe. P. 67-79. See also: Territorial heritage and development / ed. by J. M. Feria. CRC Press Taylor \& Francis group, 2012. 
Few people could know at the moment about the wider economic and social consequences of the global standstill caused by the pandemic. Certainly that the heritage systems are yet going to get affected and it is not likely to expect a considerable funding of cultural operations in near future unless relevant activities be carried out in the context of response to the crisis or development projects.

However, with a proactive attitude it is possible to mitigate the trends that are otherwise inevitable. I started from the assumption that almost any problem, however overwhelming it be, may in turn reveal some new opportunity.

\section{References}

Apaydin, Veisel (ed.). 2020. Introduction: Why cultural memory and heritage? Critical perspectives on cultural memory and heritage: construction, transformation and destruction: 1-8. London, UCL Press.

Blake, Janet. 2000. On defining the cultural heritage. The International and Comparative Law Quarterly 49 (1): 61-85.

Bold, John, Pickard, Robert (eds). 2018. An Integrated approach to cultural heritage. The Council of Europe's technical co-operation and consultancy program: 67-79. Strasbourg, Council of Europe.

Feria, Jose M. (ed.). 2012. Territorial heritage and Sustainable Development - Conceptual basis and methodological issues. Territorial heritage and development: 3-11. CRC Press Taylor \& Francis group.

Giaccardi, Elisa. 2012. Heritage and social media: Understanding heritage in a participatory culture. London, Routledge.

Howard, Patricia, Puri, Rajindra, Smith, Laura Jane, Altieri, Miguel. 2008. Globally Important Agricultural Heritage Systems: A Scientific Conceptual Framework and Strategic Principles. Available at: http://www.fao.org/3/ap025e/ap025e.pdf (accessed: 18.12.2020).

Koohafkan, Parviz, Altieri, Miguel A. 2017. Forgotten Agricultural Heritage: Reconnecting food systems and sustainable development. London, Routledge.

La Frenierre, Jeff. 2008. Mapping heritage: A participatory technique for identifying tangible and intangible cultural heritage. International Journal of the Inclusive Museum 1 (1): 97-104.

Proschan, Frank. 2015. Community involvement in valuing and safeguarding intangible cultural heritage. Van Balen, Koen and Vandesande, Aziliz A. (eds) Reflections on cultural heritage theories and practices. KU Leuven, A series by the Raymond Lemaire International Centre for conservation: $15-21$.

Riordan, Alex, Schofield, John. 2015. Beyond medicine: Traditional medicine as cultural heritage. International Journal of Heritage Studies 21: 280-299.

Russel, Lawrence Barsh. 2001. Who steals indigenous knowledge? Proceedings of the Annual Meeting (American Society of International Law) 95: 153-161.

Stamatopoulou, Elsa. 2007. Cultural rights in international law. Article 27 of the Universal declaration of human rights and beyond. Leiden, Boston, Martinus Nijhoff Publ.

Viejo-Rose, Dacia. 2015. Cultural heritage and memory: Untangling the ties that bind. Culture \& History Digital Journal 4 (2): 1-13.

Whitehead, Christopher, Bozoglu, Gonul. 2017. Heritage and Memory in Europe: a review of key concepts and frameworks. Critical heritages (Co-HERE): 2-23. Newcastle University.

Received: Jule 30, 2020

Accepted: December 23, 2020

\section{Наследие: как остаться релевантным после вирусного кризиса?}

С. Сречкович

Для цитирования: Srećković, Saša. Heritage: How to remain relevant following the virus crisis? // Правоведение. 2020. Т. 64, № 1. С. 15-22. https://doi.org/10.21638/spbu25.2020.101

В статье отмечается, что, несмотря создание в рамках ЮНЕСКО фонда, предназначенного для оказания международной помощи, благодаря которой государства - участники 
Конвенции об охране нематериального культурного наследия, в частности, могут решать проблемы, возникающие в результате катастроф и чрезвычайных ситуаций, стоит ожидать разрушительных фактических последствий пандемии для культурного наследия. В силу известных в последнее время обстоятельств - без мобильности людей и их взаимных контактов, а также без физического доступа к материальному наследию и музеям - у местных жителей, живущих в окрестностях подобных объектов, не будет никаких доходов. Другая проблема связана с нематериальным выражением наследия из-за неизбежных экономических потрясений, последовавшихза пандемией, и даже из-за недавних политических потрясений, вызванных различными связанными с ней факторами, такими как поведение, продемонстрированное различными правительствами в условиях кризиса, и последовавшие за этим бунты, вспыхнувшие по всему миру. Хотя четких решений проблем пострадавшего после кризиса наследия все еще не выработано, автор статьи предполагает, что в ближайшем будущем возрастет интерес к экологическим исследованиям, многие будут размышлять об устойчивом использовании ресурсов и их значимости для наследия (например, аграрное наследие, особенно с точки зрения продовольственной безопасности; традиционная медицина или культурные права и интеллектуальная собственность в том же контексте). Несомненно, цифровые инструменты для ознакомления с наследием со временем станут лишь прогрессировать. Вопрос заключается в том, насколько живой опыт культурного наследия окажется доступен людям, по крайней мере в предстоящий период. Адекватное реагирование на глобальное бедствие, безусловно, должно включать культурное наследие в такие стратегии, как территориальное городское/сельское планирование и различные межсекторальные мероприятия, и подобные примеры уже имеются в проектах, финансируемых и поддерживаемых Европейским союзом. Несмотря на ослабление имеющихся ресурсов в результате пандемии, институты культурного наследия должны также все чаще допускать более демократическое включение местных общин в вопросы инвентаризации и охраны этого наследия с помощью таких механизмов, как совместное картографирование и т. п.

Ключевые слова: культурное наследие, нематериальное культурное наследие, чрезвычайные ситуации, пандемия, последствия, экономические потрясения, реагирование, аграрное наследие, участие общин.

Статья поступила в редакцию: 30 июля 2020 г. Рекомендована в печать: 23 декабря 2020 г.

Сречкович Саша - бакалавр наук в области этнологии и антропологии, музейный советник, Этнографический музей, Сербия, 11000, Белград, Студенческий пр., 13; sasasrec@gmail.com 